\title{
Organic amendments of soil and its effect on the NPK contents in rice plants grown on saline soil
}

\author{
M. S. Hossain ${ }^{1 *}$, H. R. Khan and S. Akter \\ Department of Soil, Water and Environment, University of Dhaka, Dhaka 1000, Bangladesh
}

Received: 26 November 2017

Revised: 11 March 2018

Accepted: 23 May 2018

DOI: http://dx.doi.org/10.3329/bjsir.v53i4.39194

\begin{abstract}
The potential and effectiveness of the indigenous organic amendments such as rice hull (RH), rice straw (RS) and sawdust (SD) at the rates of 0,2 and $4 \mathrm{tha}^{-1}$, respectively on $\mathrm{N}, \mathrm{P}$ and $\mathrm{K}$ contents of BRRI Dhan-47 grown on saline soil under variable moisture (field moist: FM and 2-5 cm standing water: SW) levels were evaluated in the field experiment. The $\mathrm{N}, \mathrm{P}$ and $\mathrm{K}$ contents in the shoot at maturity stage of rice increased significantly $(\mathrm{p}<0.05)$ by the individual and the combined application of these amendments. The maximum contents of $\mathrm{N}\left(26.7 \mathrm{~g} \mathrm{~kg}^{-1}: \mathrm{FM}\right.$ and $\left.25.7 \mathrm{~g} \mathrm{~kg}^{-1}: \mathrm{SW}\right)$ were attained by the $\mathrm{T}_{27}\left(\mathrm{RH}_{4} \mathrm{SD}_{4} \mathrm{RS}_{4}\right)$ followed by the $\mathrm{T}_{26}\left(\mathrm{RH}_{4} \mathrm{SD}_{4} \mathrm{RS}_{2}\right)$ treatments. Among the three types of amendments regardless of their doses, the application of RS exerted best response $(16.75 \mathrm{~g}$ $\left.\mathrm{N} \mathrm{kg}^{-1}\right)$ followed by SD (16.35 $\left.\mathrm{g} \mathrm{N} \mathrm{kg}^{-1}\right)$ and $\mathrm{RH}\left(16.04 \mathrm{~g} \mathrm{~N} \mathrm{~kg}^{-1}\right)$ in increasing $\mathrm{N}$ content of rice plants at field moist condition of the soil. The maximum P contents $\left(2.49 \mathrm{~g} \mathrm{~kg}^{-1}\right.$ : FM and $2.67 \mathrm{~g} \mathrm{~kg}^{-1}$ : SW) were recorded by the $\mathrm{T}_{27}\left(\mathrm{RH}_{4} \mathrm{SD}_{4} \mathrm{RS}_{4}\right)$ followed by the $\mathrm{T}_{26}\left(\mathrm{RH}_{4} \mathrm{SD}_{4} \mathrm{RS}_{2}\right)$ treatments and the lowest contents of $\mathrm{P}\left(0.40 \mathrm{~g} \mathrm{~kg}^{-1}\right.$ : FM and $\left.0.42 \mathrm{~g} \mathrm{~kg}^{-1}: \mathrm{SW}\right)$ were obtained from the control plots. The content of $\mathrm{P}$ in rice shoots was slightly higher in SW than that of FM conditions. The maximum contents of $\mathrm{K}\left(18.2 \mathrm{~g} \mathrm{~kg}^{-1}\right.$ in FM and $15.8 \mathrm{~g} \mathrm{~kg}^{-1}$ in SW) were obtained by the application of $\mathrm{RH}_{4} \mathrm{SD}_{4} \mathrm{RS}_{4}\left(\mathrm{~T}_{27}\right)$ followed by the $\mathrm{RH}_{4} \mathrm{SD}_{4} \mathrm{RS}_{2}\left(\mathrm{~T}_{26}\right)$ and the lowest contents of $\mathrm{K}\left(2.8 \mathrm{~g} \mathrm{~kg}^{-1}: \mathrm{FM} ; 2.7\right.$ $\mathrm{g} \mathrm{kg}^{-1}: \mathrm{SW}$ ) were determined in the control plots. The contents of $\mathrm{N}$ and $\mathrm{K}$ in rice shoots were slightly higher in the FM than those of the SW conditions regardless of these amendments.
\end{abstract}

Keywords: N, P and K contents in rice plants; Rice hull, Rice straw; Sawdust and soil moisture

\section{Introduction}

Bangladesh, being an agrarian country, has a long history of rice cultivation. Rice is grown throughout the country, except for the southeastern hilly areas. The agro-climatic conditions of the country are suitable for growing rice round the year. However, the country's average rice yield is much lower (2.97 $\mathrm{t} \mathrm{ha}^{-1}$ : BBS, 2017) than those of China and Japan (6-6.5 $\left.\mathrm{tha}^{-1}\right)$. The BBS also reported that rice is the staple food for more than 160 million people of the country. The population growth rate is 2 million per year, and if the population increases at this rate, the total population will reach 238 million by 2050 (BBS, 2017). Therefore, an increase in total rice production is required to feed this ever-increasing population. Moreover, $70 \%$ of the people are directly dependent on the agricultural resources and also being a developing country, it has not attained self-sufficiency in its food production or food security (Khan et al., 2016). In addition, crop production in the coastal areas is very low (cropping intensity: $100-140 \%$ ), somewhere the lands are unproductive due to stresses of various soils and waters (Hossain et al., 2017). They also added that salinity has serious negative impacts on agriculture. During 1973 to 2009, the salinity affected area has increased from $8,330 \mathrm{~km}^{2}$ in 1973 to 10,560 in 2009 (SRDI, 2010) due to tidal flooding, direct inundation by saline water, upward and lateral movement of saline groundwater. Furthermore, cyclone and tidal surge are accelerating these problems. 
In the coastal areas of Bangladesh, saline water is used for irrigation which reduces the growth of most agricultural crops (Hossain et al., 2017). They also reported that soil salinity (electrical conductivity: $\mathrm{EC}>4 \mathrm{dS} \mathrm{m}^{-1}$ ) is a major abiotic stress which limits plant growth and development, causing yield loss in crop species. Salinity is causing a decline in soil productivity and crop yield which results in severe degradation of bio-environment and ecology as well as responsible for low cropping intensity in the coastal area. Rice has been reported as salt susceptible in both seedling and reproductive stages leading to a reduction of more than $50 \%$ in yield when exposed to 6.65 $\mathrm{dS} \mathrm{m}^{-1}$ ECe (Reddy et al., 2017).

There are various ways for the remediation and proper utilization of saline soils including agronomic practices, use of salt-tolerant crop varieties, use of indigenous organic amendments, phytoremediation, etc. The present state of knowledge demonstrated that among the different methods and techniques, use of indigenous organic amendments can be cost-effective and environmentally sound technology for the remediation of salt impacted sites and also deserve special attention for research and development of coastal salt-affected areas. Rice straw is an organic material available in significant quantities at the farmers' level. Rice straw contains numerous elements essential for plant growth including N, P and K (Gaihre et al., 2013). Approximately $40 \%$ of $\mathrm{N}, 30$ to $35 \%$ of $\mathrm{P}$, and $80-85 \%$ of $\mathrm{K}$ taken up by rice remain in the straw at crop maturity (Dobermann and Fairhurst, 2002). Conrad (2002) reported that rice straw also contains different biopolymers such as cellulose (32-37\%), hemicelluloses (29-37\%), and lignin (5-15\%). These nutrients are released from these compounds to the soil through mineralization processes and are, therefore, available for subsequent crop growth (Byous et al., 2004). Recycling of rice straw is reported to increase the organic carbon and nutrient contents in soil (Akter et al., 2017). Rice hull improved the water holding capacity of the soil. It also increased organic matter content of the soil and subsequently increased crop yield (Begum and Khan, 2014). The application of rice hull and sawdust increased organic matter content in the soil which in turn increased $\mathrm{N}$ to the soil and also increased $\mathrm{N}$ content in plant tissues (Kaniz and Khan, 2013). Water movement is one of the major problems in saline soils due to the adverse effects of salinity on soil physical properties which may be improved by the application of indigenous organic amendments like rice hull, rice straw, and sawdust. Therefore, the aim of the present study was to evaluate the potential and effectiveness of rice hull, rice straw, sawdust and moisture conditions on N P K contents in rice plant grown in a coastal saline soil.

\section{Materials and methods}

\section{Field condition}

A field experiment was conducted using BRRI Dhan-47 variety of rice in saline soil at Musulliabad, Kalapara, Patuakhali during January to May (Boro Season), 2016. The site enjoys a tropical monsoon climate and has three main seasons, namely, the monsoon or rainy season, the dry or winter season and the pre-monsoon or summer season. The monsoon season extends from May to October and is warm and humid. During this period, this locality receives about $88 \%$ of the total annual rainfall. The dry season extends from November to February and has the lowest temperature and humidity of the year. The pre-monsoon season extends from March to May and has the highest temperature and evaporation of the year.

\section{Field preparation}

Indigenous organic amendments such as rice hull (RH), rice straw (RS) and sawdust (SD) were used for the studied soil. The experiment was conducted following completely randomized block design with 3 factors, such as RH, RS and SW having 3 doses $\left(0,2,4 \mathrm{tha}^{-1}\right)$ of each with 3 replications (considered within the plot) under 2 moisture levels (Field moist: FM and $2-5 \mathrm{~cm}$ standing water conditions: SW; Fig. 1). The total number of treatment was $27(3 \mathrm{RH} \times 3 \mathrm{RS} \times 3$ SD: for each moisture level: Table I). Basal doses of $\mathrm{N}, \mathrm{P}_{2} \mathrm{O}_{5}$, and $\mathrm{K}_{2} \mathrm{O}$ were applied at the rates of 120,60 and $80 \mathrm{~kg}$ $\mathrm{ha}^{-1}$ from Urea, TSP and MoP fertilizers, respectively. The whole TSP, MoP and half of the Urea were applied during soil preparation by thorough mixing of the fertilizers with the soil. The remaining Urea was top dressed in two splits, one at active tillering and another at panicle initiation stage of rice.

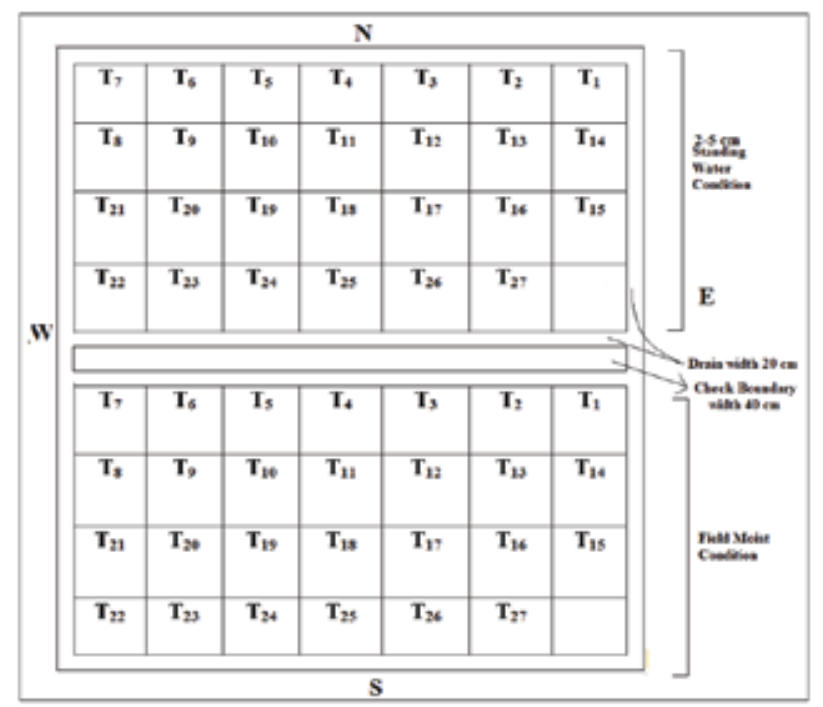

Fig. 1. The layout of the field experiment 
Table I. Treatment combinations

\begin{tabular}{cccc}
\hline & & Treatment & \\
\hline No. & Denotation & No. & Denotation \\
\hline $\mathrm{T}_{1}$ & $\begin{array}{c}\text { Control } \\
\left(\mathrm{RH}_{0} \mathrm{SD}_{0} \mathrm{RS}_{0}\right)\end{array}$ & $\mathrm{T}_{15}$ & $\mathrm{RH}_{4} \mathrm{RS}_{4}$ \\
$\mathrm{~T}_{2}$ & $\mathrm{RH}_{2}$ & $\mathrm{~T}_{16}$ & $\mathrm{SD}_{2} \mathrm{RS}_{2}$ \\
$\mathrm{~T}_{3}$ & $\mathrm{RH}_{4}$ & $\mathrm{~T}_{17}$ & $\mathrm{SD}_{2} \mathrm{RS}_{4}$ \\
$\mathrm{~T}_{4}$ & $\mathrm{SD}_{2}$ & $\mathrm{~T}_{18}$ & $\mathrm{SD}_{4} \mathrm{RS}_{2}$ \\
$\mathrm{~T}_{5}$ & $\mathrm{SD}_{4}$ & $\mathrm{~T}_{19}$ & $\mathrm{SD}_{4} \mathrm{RS}_{4}$ \\
$\mathrm{~T}_{6}$ & $\mathrm{RS}_{2}$ & $\mathrm{~T}_{20}$ & $\mathrm{RH}_{2} \mathrm{SD}_{2} \mathrm{RS}_{2}$ \\
$\mathrm{~T}_{7}$ & $\mathrm{RS}_{4}$ & $\mathrm{~T}_{21}$ & $\mathrm{RH}_{2} \mathrm{SD}_{4} \mathrm{RS}_{2}$ \\
$\mathrm{~T}_{8}$ & $\mathrm{RH}_{2} \mathrm{SD}_{2}$ & $\mathrm{~T}_{22}$ & $\mathrm{RH}_{2} \mathrm{SD}_{2} \mathrm{RS}_{4}$ \\
$\mathrm{~T}_{9}$ & $\mathrm{RH}_{2} \mathrm{RS}_{2}$ & $\mathrm{~T}_{23}$ & $\mathrm{RH}_{2} \mathrm{SD}_{4} \mathrm{RS}_{4}$ \\
$\mathrm{~T}_{10}$ & $\mathrm{RH}_{2} \mathrm{SD}_{4}$ & $\mathrm{~T}_{24}$ & $\mathrm{RH}_{4} \mathrm{SD}_{2} \mathrm{RS}_{2}$ \\
$\mathrm{~T}_{11}$ & $\mathrm{RH}_{2} \mathrm{RS}_{4}$ & $\mathrm{~T}_{25}$ & $\mathrm{RH}_{4} \mathrm{SD}_{2} \mathrm{RS}_{4}$ \\
$\mathrm{~T}_{12}$ & $\mathrm{RH}_{4} \mathrm{SD}_{2}$ & $\mathrm{~T}_{26}$ & $\mathrm{RH}_{4} \mathrm{SD}_{4} \mathrm{RS}_{2}$ \\
$\mathrm{~T}_{13}$ & $\mathrm{RH}_{4} \mathrm{RS}_{2}$ & $\mathrm{~T}_{27}$ & $\mathrm{RH}_{4} \mathrm{SD}_{4} \mathrm{RS}_{4}$ \\
$\mathrm{~T}_{14}$ & $\mathrm{RH}_{4} \mathrm{SD}_{4}$ & & \\
\hline
\end{tabular}

$\mathrm{RH}_{0}, \mathrm{RH}_{2}, \mathrm{RH}_{4}$ indicate Rice Hull @ 0, 2, 4 t ha-1 $; \mathrm{SD}_{0}, \mathrm{SD}_{2}, \mathrm{SD}_{4}$ Indicate Saw Dust @ 0, 2, 4 tha-1 and RSo, RS2, RS4 Indicate Rice straw@0,2,4 tha-1

\section{Transplantation}

Seedlings were collected from the local farmers. Thirty-days-old seedlings of BRRI Dhan-47 were transplanted at the rate of 3 seedlings per hill. The hill to hill and row to row distances were 18 and $22 \mathrm{~cm}$, respectively. For the proper establishment of the rice seedlings, all plots in the field were irrigated with pond water for two weeks after transplantation and then the moisture levels were maintained by the irrigation of same pond water. In the case of moist condition: $70 \%$ water content seemed to be enough for the survival of rice plant and did not allow standing water. But in the case of saturated condition: more than $100 \%$ water, i.e. $2-5 \mathrm{~cm}$ standing water was maintained throughout the growing period. Intercultural operations were performed as required.

\section{Soil analysis}

The physicochemical characteristics of initial soil were determined by following standard methods (Table II). The bulk soil samples were air-dried and crushed to $2 \mathrm{~mm}$ before analysis. After treatment with $1 \mathrm{M} \mathrm{CH}_{3} \mathrm{COONH}_{4}$ (pH 5.0) and with $30 \% \mathrm{H}_{2} \mathrm{O}_{2}$ to remove free salts and organic matter, respectively, particle size distribution of the initial soil was determined by the Hydrometer method (Piper, 1966). Soil pH was measured by the soil-water ratio of 1:2.5 (Jackson, 1973). The electrical conductivity was determined at a ratio soil: water $=1: 5$ (Richards, 1954). Organic matter content was determined (Nelson and Sommers, 1982) by wet combustion with $\mathrm{K}_{2} \mathrm{Cr}_{2} \mathrm{O}_{7}$. Available N (1.3 M KCl extraction, Jackson, 1973), available $\mathrm{P}\left(0.5 \mathrm{M} \mathrm{NaHCO}_{3}, \mathrm{pH} 8.5\right.$ extraction, Olsen et al., 1954), available $\mathrm{K}$ (Pratt, 1965) and available $\mathrm{S}\left(\mathrm{BaCl}_{2}\right.$ turbidity, Sakai, 1978) were determined. Cation exchange capacity was determined by saturation with $1 \mathrm{M} \mathrm{CH}_{3} \mathrm{COONH}_{4}$ ( $\mathrm{pH} 7.0$ ), ethanol washing, $\mathrm{NH}_{4}^{+}$displacement with acidified $10 \% \mathrm{NaCl}$, and subsequent analysis by steam (Kjeldhal method) distillation (Chapman, 1965). Exchangeable $\mathrm{Na}^{+}, \mathrm{K}^{+}$, $\mathrm{Ca}^{2+}$ and $\mathrm{Mg}^{2+}$ were extracted with $1 \mathrm{M} \mathrm{CH}_{3} \mathrm{COONH}_{4}(\mathrm{pH} 7.0$ ) and determined by flame photometry $\left(\mathrm{Na}^{+}, \mathrm{K}^{+}\right)$and atomic absorption spectrometry $\left(\mathrm{Ca}^{+}, \mathrm{Mg}^{+}\right)$.

\section{Plant analysis}

Plant samples were collected after harvesting the crop at maturity. The plants per plot were cut at the $1 \mathrm{~cm}$ above ground level.The $\mathrm{N}$ contents were analyzed by the $\mathrm{H}_{2} \mathrm{SO}_{4}$ digestion through the micro-Kjeldhal method (Jackson, 1973) and P contents by spectrophotometry (Jackson, 1973); K contents by Gallenkamp flame photometry (Black, 1965). The analysis of variance (ANOVA) of the data and the test of significance of the different treatment means were assessed by Tukey’s Range Test at 5\% $(\mathrm{p}<0.05)$ level.

\section{Results and discussion}

\section{Changes in nitrogen content}

The studied rice plants grown in saline soil harvested at maturity and the nitrogen content in the analysed tissues was found to have a positive significant $(\mathrm{p}<0.05)$ influence by the individual application of rice hull, rice straw and sawdust treatments, though their higher rates and combinations were found to have more effective in increasing in $\mathrm{N}$ content than that of their individual treatments. The highest contents of $\mathrm{N}$ (26.7 $\mathrm{g} \mathrm{kg}^{-1}$ in FM and $25.7 \mathrm{~g} \mathrm{~kg}^{-1}$ in SW) were attained by the application of the $\mathrm{T}_{27}\left(\mathrm{RH}_{4} \mathrm{SD}_{4} \mathrm{RS}_{4}\right)$ followed by the $\mathrm{T}_{26}$ $\left(\mathrm{RH}_{4} \mathrm{SD}_{4} \mathrm{RS}_{2}\right)$ treatment and the lowest contents of $\mathrm{N}(6.7 \mathrm{~g}$ $\mathrm{kg}^{-1}$ in FM and $6.5 \mathrm{~g} \mathrm{~kg}^{-1}$ in SW) were obtained from the control plots (Fig. 2). Among the three types of amendments regardless of their doses $\left(2,4 \mathrm{tha}^{-1}\right)$, the individual application of rice straw exerted best response (16.75 $\mathrm{g} \mathrm{N} \mathrm{kg}^{-1}$ of rice straw) followed by sawdust (16.35 $\left.\mathrm{g} \mathrm{kg}^{-1}\right)$ and rice hull $\left(16.04 \mathrm{~g} \mathrm{~kg}^{-1}\right)$ in increasing $\mathrm{N}$ content of rice shoot at moist condition of the soil (Table III). The amendments were found less effective (rice straw $14.99 \mathrm{~g} \mathrm{~N} \mathrm{~kg}^{-1}$ of rice straw, sawdust $14.71 \mathrm{~g} \mathrm{~kg}^{-1}$ and rice hull $14.20 \mathrm{~g} \mathrm{~kg}^{-1}$ ) under the standing water condition (Table III). It was also recorded that the contents of $\mathrm{N}$ in rice shoots were slightly higher in the FM than that of the SW conditions, 
Table II. Physico-chemical characteristics of initial soil $(1-15 \mathrm{~cm})$ on oven dry basis

\begin{tabular}{|c|c|}
\hline Properties & Values \\
\hline Textural Class ( Hydrometer Method) & Silty Clay Loam \\
\hline Soil pH ( Soil: Water = 1: 2.5) & 6.3 \\
\hline EC $\left(\right.$ Soil $:$ Water $\left.=1: 5, \mathrm{dS} \mathrm{m}^{-1}\right)$ & 4.17 \\
\hline Organic Carbon ( $\mathrm{g} \mathrm{kg}^{-1}$, wet oxidation method) & 14.3 \\
\hline Total N (Micro Kjeldahl Method, $\mathrm{g} \mathrm{kg}^{-1}$ ) & 1.4 \\
\hline $\mathrm{C} / \mathrm{N}$ ratio & 10.20 \\
\hline Cation Exchange Capacity $\left(\mathrm{C}\right.$ mol kg $\left.{ }^{-1}\right)$ & 21.23 \\
\hline Available N (mg kg${ }^{-1}$, Micro Kjeldahl Method) & 42 \\
\hline Available S (mg kg ${ }^{-1}$, Spectrophotometer) & 192 \\
\hline Available P (mg kg${ }^{-1}$, Spectrophotometer) & 14 \\
\hline Available K (mg kg-1, Flame photometer) & 24.16 \\
\hline Base Saturation Percentage & 53.32 \\
\hline \multicolumn{2}{|l|}{ Exchangeable Cations : } \\
\hline $\mathrm{Na}^{+}\left(\mathrm{C}\right.$ mol kg${ }^{-1}$, Flame Photometer $)$ & 4.02 \\
\hline $\mathrm{K}^{+}\left(\mathrm{C}\right.$ mol kg${ }^{-1}$, Flame Photometer $)$ & 1.90 \\
\hline $\mathrm{Ca}^{2+}$ (C mol kg ${ }^{-1}$, Atomic Adsorption Spectrophotometry) & 2.90 \\
\hline $\mathrm{Mg}^{2+}\left(\mathrm{C} \mathrm{mol} \mathrm{kg}{ }^{-1}\right.$, Atomic Adsorption Spectrophotometry $)$ & 2.50 \\
\hline \multicolumn{2}{|l|}{ Water Soluble Ions : } \\
\hline $\mathrm{Cl}^{-}\left(\mathrm{C} \mathrm{mol} \mathrm{L}{ }^{-1}\right)$ & 2.63 \\
\hline $\mathrm{SO}_{4}^{-2}\left(\mathrm{C} \mathrm{mol} \mathrm{L}^{-1}\right)$ & 1.75 \\
\hline Carbonate $\left(\mathrm{C} \mathrm{mol} \mathrm{L}^{-1}\right)$ & Nil \\
\hline Bicarbonate $\left(\mathrm{C} \mathrm{mol} \mathrm{L}^{-1}\right)$ & 0.98 \\
\hline Sodium Adsorption Ratio (SAR) & 2.45 \\
\hline Exchangeable Sodium Percentage (ESP) & 18.9 \\
\hline
\end{tabular}

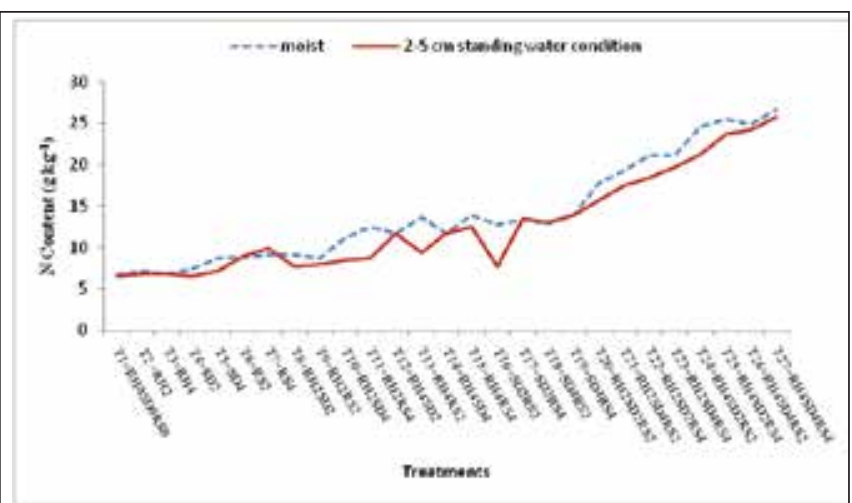

Fig. 2. The nitrogen content in plant tissues of rice (BRRI Dhan-47) as influenced by the application of rice hull, rice straw and sawdust under variable moisture conditions

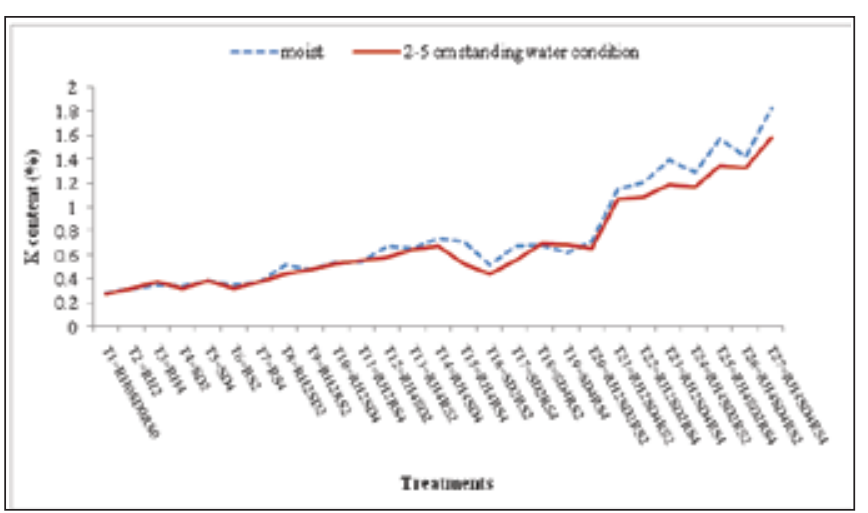

Fig. 3. The phosphorus content in plant tissues of rice (BRRI Dhan-47) as influenced by the application of rice hull, rice straw and sawdust under variable moisture conditions 
which might be due to the more oxidation state of the growing medium in the FM. Based on the superiority of the treatments, in increasing the nitrogen content of rice plant, the order of the treatments should be arranged in the following sequence under the FM condition:

$\mathrm{T}_{27}>\mathrm{T}_{25}>\mathrm{T}_{26}>\mathrm{T}_{24}>\mathrm{T}_{23}>\mathrm{T}_{22}>\mathrm{T}_{21}>\mathrm{T}_{20}>\mathrm{T}_{19}>\mathrm{T}_{13}$ $>T_{17}>T_{18}>T_{15}>T_{11}>T_{16}>T_{14}>T_{2}>T_{10}>T_{7}>T_{8}>T_{6}>$ $\mathrm{T}_{16}>\mathrm{T}_{4}>\mathrm{T}_{2}>\mathrm{T}_{1}>\mathrm{T}_{3}$

The present results are partially agreed with the earlier findings of Kaniz and Khan (2013). They carried out an experiment using gypsum, rice hull, and rice straw to reclaim saline soil. They reported that $\mathrm{N}$ content in plant straw was increased by the application of rice hull and saw dust as these treatments added organic matter, in turn, $\mathrm{N}$ to the soil. They also reported that $\mathrm{N}$ content in plant tissues was found to be increasedby the application of rice hull and sawdust at the rate of $6 \mathrm{t} \mathrm{ha}^{-1}$ but declined with the highest rate of $9 \mathrm{t} \mathrm{ha}^{-1}$ of these organic amendments, which might be due to release of acid to the toxic level by the higher doses of organic amendments that inhibits plant growth as well as $\mathrm{N}$ uptake. But in the present experiment, the doses $\left(2,4 \mathrm{tha}^{-1}\right)$ of these treatments of $\mathrm{RH}, \mathrm{RS}$ and $\mathrm{SD}$ and their combinations were found to have a significant positive influence on the $\mathrm{N}$ contents of rice plants grown both under the FM and the SW conditions. No evidence of negative influences was noticed which demonstrated that the present doses of the applied amendments were optimum for the studied soil.

\section{Changes in Phosphorus content}

The application of organic amendments at variable rates individually or in combinations showed a significant $(p<0.05)$ positive influence on the phosphorus contents of rice plants grown under both the FM and the SW conditions. These effects were more pronounced with their higher doses of the treatments and their combinations. The maximum $\mathrm{P}$ contents (2.49 $\mathrm{g} \mathrm{kg}^{-1}$ in FM and $2.67 \mathrm{~g} \mathrm{~kg}^{-1}$ in SW) were recorded by the application of the $\mathrm{T}_{27}\left(\mathrm{RH}_{4} \mathrm{SD}_{4} \mathrm{RS}_{4}\right)$ followed by the $\mathrm{T}_{26}$ $\left(\mathrm{RH}_{4} \mathrm{SD}_{4} \mathrm{RS}_{2}\right)$ treatments and the lowest contents of $\mathrm{P}(0.40 \mathrm{~g}$ $\mathrm{kg}^{-1}$ in FM and $0.42 \mathrm{~g} \mathrm{~kg}^{-1}$ in SW) were obtained from the control plots (Fig. 3). It was also observed that the contents of phosphorus in rice shoots were slightly higher in the SW than that of the FM condition, which indicates that phosphorus mobility or uptake by plants was better in the SW condition. This might be due to the favorable $\mathrm{pH}$ condition attained by the application of rice hull, rice straw and sawdust, resulting in good nutrition of $\mathrm{P}$ in plants. Brady and Weil (1996) reported that organic materials release phosphorus from

Table III. Comparison of Nitrogen contents $\left(\mathrm{g} \mathrm{kg}^{-1}\right)$ in plant tissues of rice under (a) Field moist and (b) Standing water conditions as influenced by the application of rice hull (RH), rice straw (RS) and sawdust (SD)

\begin{tabular}{|c|c|c|c|c|c|c|c|}
\hline \multirow{2}{*}{\multicolumn{2}{|c|}{$\mathrm{RH} \times \mathrm{RS} \times \mathrm{SD}$}} & \multirow{2}{*}{$\begin{array}{l}\text { Rice Straw } \\
\left(\mathrm{RS}: \mathrm{t} \mathrm{ha}^{-1}\right)\end{array}$} & \multicolumn{3}{|c|}{ Saw Dust (SD: $\mathrm{t} \mathrm{ha}^{-1}$ ) } & \multirow{2}{*}{$\begin{array}{l}\text { RH- } \\
\text { mean }\end{array}$} & \multirow[t]{2}{*}{ RS- mean } \\
\hline & & & $\mathbf{0}$ & 2 & 4 & & \\
\hline \multicolumn{8}{|c|}{ (a) Field Moist Condition (FM) } \\
\hline \multirow{9}{*}{ 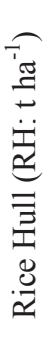 } & & $\mathbf{0}$ & $6.7 \mathrm{x}$ & $7.5 \mathrm{t}$ & $8.7 \mathrm{~s}$ & \multirow{3}{*}{$10.42 \mathrm{c}$} & \multirow{3}{*}{$\begin{array}{c}9.0 \mathrm{c} \\
\left(0 \mathrm{t} \mathrm{ha}^{-1}\right)\end{array}$} \\
\hline & \multirow[t]{2}{*}{$\mathbf{0}$} & 2 & $8.9 \mathrm{r}$ & $12.7 \mathrm{~m}$ & 12.91 & & \\
\hline & & 4 & $9.1 \mathrm{r}$ & $13.4 \mathrm{k}$ & $13.9 \mathrm{i}$ & & \\
\hline & \multirow{3}{*}{2} & $\mathbf{0}$ & $7.2 \mathrm{u}$ & $9.1 \mathrm{r}$ & $11.2 \mathrm{q}$ & \multirow{3}{*}{$14.25 b$} & \multirow{3}{*}{$\begin{array}{c}16.0 \mathrm{~b} \\
\left(2 \mathrm{t} \mathrm{ha}^{-1}\right)\end{array}$} \\
\hline & & 2 & $8.7 \mathrm{~s}$ & $17.8 \mathrm{~h}$ & $19.4 \mathrm{~g}$ & & \\
\hline & & 4 & $12.5 \mathrm{n}$ & $21.2 \mathrm{f}$ & $21.2 \mathrm{e}$ & & \\
\hline & \multirow{3}{*}{4} & $\mathbf{0}$ & $6.8 \mathrm{w}$ & $12.4 \mathrm{o}$ & $11.7 \mathrm{p}$ & \multirow{3}{*}{$17.82 \mathrm{a}$} & \multirow{3}{*}{$\begin{array}{c}17.5 \mathrm{a} \\
\left(4 \mathrm{tha}^{-1}\right)\end{array}$} \\
\hline & & 2 & $13.7 \mathrm{j}$ & $24.7 \mathrm{~d}$ & $24.9 \mathrm{c}$ & & \\
\hline & & 4 & $13.9 \mathrm{i}$ & $25.6 \mathrm{~b}$ & $26.7 \mathrm{a}$ & & \\
\hline \multicolumn{3}{|c|}{ Saw Dust (SD)-mean } & $9.7 \mathrm{c}$ & $16.0 \mathrm{~b}$ & $16.7 \mathrm{a}$ & & \\
\hline \multicolumn{8}{|c|}{ (b) Standing Water Condition (SW) } \\
\hline \multirow{9}{*}{ 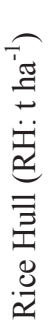 } & & 0 & $6.5 \mathrm{x}$ & $6.5 \mathrm{x}$ & $7.2 \mathrm{u}$ & \multirow{3}{*}{$9.6 \mathrm{c}$} & \multirow{3}{*}{$\begin{array}{c}7.9 \mathrm{c} \\
\left(0 \mathrm{th}^{-1}\right)\end{array}$} \\
\hline & $\mathbf{0}$ & 2 & $8.9 \mathrm{r}$ & $7.6 \mathrm{t}$ & $12.9 \mathrm{k}$ & & \\
\hline & & 4 & 9.8 o & $13.4 \mathrm{j}$ & $13.9 \mathrm{i}$ & & \\
\hline & & $\mathbf{0}$ & $6.7 \mathrm{w}$ & $7.6 \mathrm{t}$ & $8.4 \mathrm{r}$ & \multirow{3}{*}{$12.3 \mathrm{~b}$} & \multirow{3}{*}{$\begin{array}{l}13.87 \mathrm{~b} \\
\left(2 \mathrm{t} \mathrm{ha}^{-1}\right)\end{array}$} \\
\hline & \multirow[t]{2}{*}{2} & 2 & $7.9 \mathrm{r}$ & $15.6 \mathrm{~h}$ & $17.4 \mathrm{~g}$ & & \\
\hline & & 4 & $8.7 \mathrm{~s}$ & $18.3 \mathrm{f}$ & $19.7 \mathrm{e}$ & & \\
\hline & \multirow{3}{*}{4} & $\mathbf{0}$ & $6.8 \mathrm{v}$ & 9.8 o & $11.7 \mathrm{~m}$ & \multirow{3}{*}{$16.1 \mathrm{a}$} & \multirow{3}{*}{$\underset{\left(4 \mathrm{t} \mathrm{ha}^{-1}\right)}{16.1 \mathrm{a}}$} \\
\hline & & 2 & $9.3 \mathrm{p}$ & $21.2 \mathrm{~d}$ & $24.1 \mathrm{~b}$ & & \\
\hline & & 4 & 12.41 & $23.7 \mathrm{c}$ & $25.7 \mathrm{a}$ & & \\
\hline \multicolumn{3}{|c|}{ Saw Dust (SD)-mean } & $8.47 \mathrm{c}$ & $13.74 \mathrm{~b}$ & $15.67 \mathrm{a}$ & & \\
\hline
\end{tabular}

In a column and row, means followed by a common letter are not significantly different at $5 \%$ level 
Table IV. Comparison of Phosphorus contents $\left(\mathrm{g} \mathrm{kg}^{-1}\right)$ in plant tissues of rice under (a) Field moist and (b) Standing water conditions as influenced by the application of rice hull (RH), rice straw (RS) and sawdust (SD)

\begin{tabular}{|c|c|c|c|c|c|c|c|}
\hline \multirow{2}{*}{\multicolumn{2}{|c|}{$\mathrm{RH} \times \mathrm{RS} \times \mathrm{SD}$}} & \multirow{2}{*}{$\begin{array}{l}\text { Rice Straw } \\
\left(\mathrm{RS}: \mathrm{t} \mathrm{ha}^{-1}\right)\end{array}$} & \multicolumn{3}{|c|}{ Saw Dust (SD: $\mathrm{t} \mathrm{ha}^{-1}$ ) } & \multirow{2}{*}{$\begin{array}{l}\text { RH- } \\
\text { mean }\end{array}$} & \multirow[t]{2}{*}{ RS- mean } \\
\hline & & & 0 & 2 & 4 & & \\
\hline \multicolumn{8}{|c|}{ (a) Field Moist Condition (FM) } \\
\hline \multirow{9}{*}{ 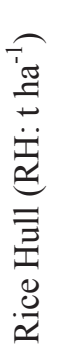 } & & $\mathbf{0}$ & $0.40 \mathrm{~W}$ & $0.43 \mathrm{v}$ & $0.51 \mathrm{~s}$ & \multirow{3}{*}{$0.71 \mathrm{c}$} & \multirow{3}{*}{$\begin{array}{l}0.67 \mathrm{c} \\
\left(0 \mathrm{t} \mathrm{ha}^{-1}\right)\end{array}$} \\
\hline & \multirow[t]{2}{*}{$\mathbf{0}$} & 2 & $0.47 \mathrm{u}$ & $0.67 \mathrm{q}$ & $1.17 \mathrm{j}$ & & \\
\hline & & 4 & $0.53 \mathrm{r}$ & 1.121 & $1.03 \mathrm{~m}$ & & \\
\hline & \multirow{3}{*}{2} & $\mathbf{0}$ & $0.47 \mathrm{u}$ & $0.67 \mathrm{q}$ & $0.69 \mathrm{p}$ & \multirow{3}{*}{$1.13 \mathrm{~b}$} & \multirow{3}{*}{$\begin{array}{c}1.29 \mathrm{~b} \\
\left(2 \mathrm{t} \mathrm{ha}^{-1}\right)\end{array}$} \\
\hline & & 2 & $0.67 \mathrm{q}$ & $1.53 \mathrm{~h}$ & $1.75 \mathrm{f}$ & & \\
\hline & & 4 & $0.91 \mathrm{o}$ & $1.67 \mathrm{~g}$ & $1.83 \mathrm{e}$ & & \\
\hline & \multirow{3}{*}{4} & $\mathbf{0}$ & $0.64 \mathrm{r}$ & 1.121 & $1.08 \mathrm{~m}$ & \multirow{3}{*}{$1.54 \mathrm{a}$} & \multirow{3}{*}{$\begin{array}{c}1.42 \mathrm{a} \\
\left(4 \mathrm{t} \mathrm{ha}^{-1}\right)\end{array}$} \\
\hline & & 2 & $0.91 \mathrm{o}$ & $2.24 \mathrm{~b}$ & $2.22 \mathrm{c}$ & & \\
\hline & & 4 & $1.14 \mathrm{k}$ & $2.07 \mathrm{~d}$ & $2.49 \mathrm{a}$ & & \\
\hline \multicolumn{3}{|c|}{ Saw Dust (SD)-mean } & $0.68 \mathrm{c}$ & $1.28 \mathrm{~b}$ & $1.42 \mathrm{a}$ & & \\
\hline \multicolumn{8}{|c|}{ (b) Standing Water condition (SW) } \\
\hline \multirow{9}{*}{ 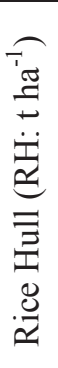 } & \multirow{4}{*}{$\mathbf{0}$} & $\mathbf{0}$ & $0.42 \mathrm{y}$ & $0.66 \mathrm{w}$ & $0.69 \mathrm{v}$ & \multirow{3}{*}{$0.93 \mathrm{c}$} & \multirow{3}{*}{$\begin{array}{l}0.77 \mathrm{c} \\
\left(0 \mathrm{t} \mathrm{ha}^{-1}\right)\end{array}$} \\
\hline & & 2 & $0.74 \mathrm{u}$ & 1.241 & $1.27 \mathrm{j}$ & & \\
\hline & & 4 & $0.81 \mathrm{~s}$ & $1.18 \mathrm{~m}$ & $1.38 \mathrm{~h}$ & & \\
\hline & & $\mathbf{0}$ & $0.57 \mathrm{x}$ & $0.95 \mathrm{p}$ & $0.78 \mathrm{t}$ & \multirow{3}{*}{$1.17 \mathrm{~b}$} & \multirow{3}{*}{$\begin{array}{c}1.39 \mathrm{~b} \\
\left(2 \mathrm{t} \mathrm{ha}^{-1}\right)\end{array}$} \\
\hline & \multirow[t]{2}{*}{2} & 2 & $0.87 \mathrm{r}$ & $1.53 \mathrm{~g}$ & $1.57 \mathrm{f}$ & & \\
\hline & & 4 & $0.92 \mathrm{q}$ & $1.67 \mathrm{e}$ & $1.74 \mathrm{c}$ & & \\
\hline & \multirow{3}{*}{4} & $\mathbf{0}$ & $0.64 \mathrm{w}$ & 0.98 o & $1.26 \mathrm{k}$ & \multirow{3}{*}{$1.57 \mathrm{a}$} & \multirow{3}{*}{$\begin{array}{c}1.51 \mathrm{a} \\
\left(4 \mathrm{t} \mathrm{ha}^{-1}\right)\end{array}$} \\
\hline & & 2 & $1.17 \mathrm{n}$ & $1.71 \mathrm{~d}$ & $2.41 \mathrm{~b}$ & & \\
\hline & & 4 & $1.34 \mathrm{i}$ & $1.71 \mathrm{~d}$ & $2.67 \mathrm{a}$ & & \\
\hline \multicolumn{3}{|c|}{ Saw Dust (SD)-mean } & $0.83 \mathrm{c}$ & $1.37 \mathrm{~b}$ & $1.53 \mathrm{a}$ & & \\
\hline
\end{tabular}

In a column and row, means followed by a common letter are not significantly different at $5 \%$ level

mineralization under the reduced condition and canimprove phosphorus availability by reducing the tendency ofthe mineral fractions to fix phosphorus. Polthanee et al. (2011) suggested that the incorporation of rice straw into the soil combined with the cattle manure obtained the maximum $\mathrm{P}(0.267 \%)$ content of the stem of rice which are also agreed with the present findings.

\section{Changes in Potassium content}

The content of potassium in the rice shoot at maturity was found to be increased significantly $(p<0.05)$ with the increased level of treatments and their combinations. The highest contents of $\mathrm{K}(1.82 \%$ in FM and $1.58 \%$ in SW) were obtained by the application of the $\mathrm{T}_{27}\left(\mathrm{RH}_{4} \mathrm{SD}_{4} \mathrm{RS}_{4}\right)$ followed by the $\mathrm{T}_{26}\left(\mathrm{RH}_{4} \mathrm{SD}_{4} \mathrm{RS}_{2}\right)$ treatment and the lowest contents of $\mathrm{K}(0.28 \%$ in $\mathrm{FM}$ and $0.27 \%$ in SW) were obtained from the control plot (Fig. 4). It was also observed that contents of potassium in rice shoots were slightly higher in the FM than that of the SW condition, which might be due to fixation and release, and ultimately loses potassium under the standing water condition. Ashrafi et al. (2010) conducted a study on the effects of organic manures (cow dung, poultry manure, water hyacinth compost and wild aroid scompost) on nitrogen, phosphorus and potassium contents ingrain, husk, stem and root of rice grown in an arsenic-contaminated soil and reported that in straw, with the application of different

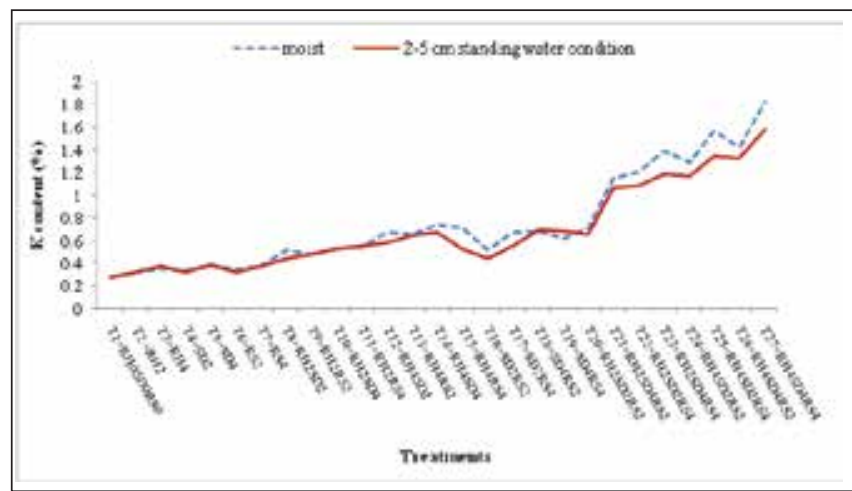

Fig. 4. The potassium content in plant tissues of rice (BRRI Dhan-47) as influenced by the application of rice hull, rice straw and sawdust under variable moisture conditions 
Table V. Comparison of Potassium contents (\%) in plant tissues of rice under (a) Field moist and (b) Standing water conditions as influenced by the application of rice hull (RH), rice straw (RS) and sawdust (SD)

\begin{tabular}{|c|c|c|c|c|c|c|c|}
\hline \multirow{2}{*}{\multicolumn{2}{|c|}{$\mathrm{RH} \times \mathrm{RS} \times \mathrm{SD}$}} & \multirow{2}{*}{$\begin{array}{l}\text { Rice Straw } \\
\left(\mathrm{RS}: \mathrm{t} \mathrm{ha}^{-1}\right)\end{array}$} & \multicolumn{3}{|c|}{ Saw Dust (SD: $\left.\mathrm{t} \mathrm{ha}^{-1}\right)$} & \multirow{2}{*}{$\begin{array}{l}\text { RH- } \\
\text { mean }\end{array}$} & \multirow[t]{2}{*}{ RS- mean } \\
\hline & & & 0 & 2 & 4 & & \\
\hline \multicolumn{8}{|c|}{ (a) Field Moist Condition (FM) } \\
\hline \multirow{9}{*}{ 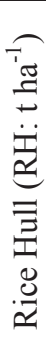 } & \multirow{3}{*}{$\mathbf{0}$} & $\mathbf{0}$ & $0.28 \mathrm{x}$ & $0.34 \mathrm{w}$ & $0.38 \mathrm{~s}$ & \multirow{3}{*}{$0.47 \mathrm{c}$} & \multirow{3}{*}{$\begin{array}{l}0.91 \mathrm{~b} \\
\left(0 \mathrm{t} \mathrm{ha}^{-1}\right)\end{array}$} \\
\hline & & 2 & $0.35 \mathrm{u}$ & $0.51 \mathrm{q}$ & $0.68 \mathrm{j}$ & & \\
\hline & & 4 & $0.37 \mathrm{t}$ & $0.67 \mathrm{k}$ & $0.62 \mathrm{n}$ & & \\
\hline & \multirow{3}{*}{2} & $\mathbf{0}$ & $0.32 \mathrm{w}$ & $0.51 \mathrm{q}$ & $0.53 \mathrm{p}$ & \multirow{3}{*}{$0.76 \mathrm{~b}$} & \multirow{3}{*}{$\begin{array}{c}0.80 \mathrm{c} \\
\left(2 \mathrm{t} \mathrm{ha}^{-1}\right)\end{array}$} \\
\hline & & 2 & $0.48 \mathrm{r}$ & $0.71 \mathrm{i}$ & $1.15 \mathrm{~g}$ & & \\
\hline & & 4 & $0.54 \mathrm{o}$ & $1.20 \mathrm{f}$ & $1.39 \mathrm{~d}$ & & \\
\hline & \multirow{3}{*}{4} & $\mathbf{0}$ & $0.35 \mathrm{w}$ & $0.67 \mathrm{k}$ & $0.74 \mathrm{~h}$ & \multirow{3}{*}{$1.02 \mathrm{a}$} & \multirow{3}{*}{$\begin{array}{c}0.99 \mathrm{a} \\
\left(4 \mathrm{t} \mathrm{ha}^{-1}\right)\end{array}$} \\
\hline & & 2 & $0.65 \mathrm{~m}$ & $1.29 \mathrm{e}$ & $1.42 \mathrm{c}$ & & \\
\hline & & 4 & $0.71 \mathrm{i}$ & $1.57 \mathrm{~b}$ & $1.82 \mathrm{a}$ & & \\
\hline \multicolumn{3}{|c|}{ Saw Dust (SD)-mean } & $0.45 \mathrm{c}$ & $0.83 \mathrm{~b}$ & $0.97 \mathrm{a}$ & & \\
\hline \multicolumn{8}{|c|}{ (b) Standing Water condition (SW) } \\
\hline \multirow{9}{*}{ 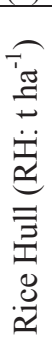 } & & $\mathbf{0}$ & $0.27 \mathrm{t}$ & $0.32 \mathrm{~s}$ & $0.38 \mathrm{q}$ & \multirow{3}{*}{$0.45 \mathrm{c}$} & \multirow{3}{*}{$\begin{array}{l}0.43 \mathrm{c} \\
\left(0 \mathrm{t} \mathrm{ha}^{-1}\right)\end{array}$} \\
\hline & $\mathbf{0}$ & 2 & $0.32 \mathrm{~s}$ & $0.44 \mathrm{p}$ & $0.69 \mathrm{~h}$ & & \\
\hline & & 4 & $0.37 \mathrm{r}$ & $0.55 \mathrm{~m}$ & $0.68 \mathrm{i}$ & & \\
\hline & \multirow{3}{*}{2} & $\mathbf{0}$ & $0.32 \mathrm{~s}$ & $0.44 \mathrm{p}$ & $0.52 \mathrm{n}$ & \multirow{3}{*}{$0.70 \mathrm{~b}$} & \multirow{3}{*}{$\begin{array}{l}0.76 \mathrm{ab} \\
\left(2 \mathrm{t} \mathrm{ha}^{-1}\right)\end{array}$} \\
\hline & & 2 & 0.48 o & $0.65 \mathrm{j}$ & $1.07 \mathrm{~g}$ & & \\
\hline & & 4 & 0.551 & $1.08 \mathrm{f}$ & $1.19 \mathrm{~d}$ & & \\
\hline & \multirow{3}{*}{4} & $\mathbf{0}$ & $0.38 \mathrm{q}$ & $0.58 \mathrm{k}$ & $0.67 \mathrm{i}$ & \multirow{3}{*}{$0.91 \mathrm{a}$} & \multirow{3}{*}{$\begin{array}{c}0.87 \mathrm{a} \\
\left(4 \mathrm{tha}^{-1}\right)\end{array}$} \\
\hline & & 2 & $0.64 \mathrm{k}$ & $1.17 \mathrm{e}$ & $1.33 \mathrm{c}$ & & \\
\hline & & 4 & $0.52 \mathrm{n}$ & $1.35 \mathrm{~b}$ & $1.58 \mathrm{a}$ & & \\
\hline \multicolumn{3}{|c|}{ Saw Dust (SD)-mean } & $0.43 \mathrm{c}$ & $0.73 \mathrm{~b}$ & $0.90 \mathrm{a}$ & & \\
\hline
\end{tabular}

In a column and row, means followed by a common letter are not significantly different at $5 \%$ level

organic manures, the highest contents of $\mathrm{N}, \mathrm{P}$ and $\mathrm{K}$ in rice plant tissues were $0.77 \%, 0.88 \%$, and $1.66 \%$ respectively. The present findings showed that highest contents of N (2.67\%: FM, 2.57\%: SW), P (0.24\%: FM, 0.28\%: SW), K (1.82\%: FM, $1.58 \%$ : SW) were obtained by application of highest doses of the RH, RS and SD treatments with their combinations and are in agreement with the above findings. Regardless of rates of the amendments, rice hull, rice straw and sawdust (mean values of RH, RS, SD; Table IV and V) exerted almost similar positive effects on the N, P and K contents in rice shoots, but the effects varied under variable moisture conditions. The trend of the effect of the amendments was always similar for $\mathrm{N}$ and $\mathrm{K}$ uptake regardless of treatments and moisture conditions, which might be due to their synergistic nature of the $\mathrm{N}$ and $\mathrm{K}$.

\section{Conclusion}

The findings concluded that the application of rice hull, rice straw and sawdust individually or in combinations increased the nitrogen, phosphorus and potassium nutrition of rice under both the field moist and the standing water conditions. The synergistic nature of $\mathrm{N}$ and $\mathrm{K}$ uptake by plants were also confirmed by the treatments, regardless of their kinds, application rates and condition of the experiment though the $\mathrm{P}$ contents in the rice plants showed almost a reverse trend. The maximum $\mathrm{N}, \mathrm{P}$ and $\mathrm{K}$ contents in rice plant tissues were determined by the highest rate and combinations of the treatments under both the FM and the SW conditions. Among the amendments, regardless of their doses, rice straw exerted the best response followed by sawdust and rice hull in increasing $\mathrm{N}$ and $\mathrm{K}$ contents of rice plants under the moist condition of the soil. With the combined application of higher doses of these amendments, different responses by the rice plants were observed due to moisture variations, which suggest that optimum moisture condition of the saline soil is prerequisite when the application of organic amendments are considered in order to boost up the nutritional value of rice.

\section{Acknowledgement}

The study was carried out under the project entitled 'Multidisciplinary Approaches for Green Transformation and Development of Agriculture in Salt-affected Coastal Soils Under Changing Climatic Conditions' funded by the Ministry of Science and Technology (Ref. MOST No. BS-109/1038/2015-2016 dated 08.12.2015). We are grateful to the ministry of Science and Technology for providing NST fellowships for the $1^{\text {st }}$ and $3^{\text {rd }}$ authors (Ref. MOST No.39.00.0000.012.20.004.16-409 dated 04.09. 2016).

\section{References}

Akter S, Khan HR and Hossain MS (2017), Potentials of Rice straw, Rice hull and Sawdust on the Growth and Yield performance of Rice Grown under variable moisture 
conditions in a Saline Soil, Journal of the Asiatic Society of Bangladesh 43(2): 197-206.

Ashrafi R, Biswas MHR, Mustafizur Rahman GKM, Khatun $R$ and Islam MR (2010), Effect of Organic Manure on Nutrient Contents of Rice Grown in an Arsenic Contaminated Soil, Bangladesh Journal of Scientific and Industrial Research 45(3): 183-188. DOI: 10.3329/bjsir.v45i3.6526

BBS, Bangladesh Bureau of Statistics (2017), Yearbook of Agricultural Statistics-2016, Planning Division, Ministry of planning, Government of the people's republic of Bangladesh, Dhaka.

Begum M and Khan HR (2014), Physico-chemical characteristics of saline soil under wheat as influenced by gypsum, rice hull and different salinity levels, International J. Res. Applied Nat. and Social Sci. 298: 121-126.

Black CA (ed.) (1965), Methods of soil analysis, Part 2, Series 9, Am Soc. Agron, pp 894-1372.

Brady NC and Weil RR (1996), The Nature and Properties of Soils, $11^{\text {th }}$ Ed. Prentice Hall, Upper Saddle River, New Jersey , pp 361-473.

BRRI (2015), Modern Rice Cultivation, $18^{\text {th }}$ Ed.

Byous EW, Williams JE, Jonesa GE, Horwath WR and Kessel C (2004), Nutrient requirements of rice with alternative straw management, Better Crops 36: 6-11.

Chapman HD (1965), Cation exchange capacity In: Methods of soil analysis, Part 2, Ed. Black CA, Agrn. Series 9, Am. Soc. Agron. Publ., Madison, WI, USA, pp 891-900.

Conrad R (2002), Control of microbial methane production in wetland rice fields, Nut. Cyc. in Agro. 64: 59-69.

Dobermann A and Fairhurst TH (2002), Rice Straw Management In: Taken from Better Crops International, Special supplement publication: Rice Production, vol. 16 Published by the Potash and Phosphate Institute of Canada.

Gaihre YK, Wassmann R and Villegas-Pangga G (2013), Impact of elevated temperatures on greenhouse gas emissions in rice systems: interaction with straw incorporation studied in a growth chamber experiment, Plant Soil 373: 857-875.

Hoque MA, Saika U, Sarder BC and Biswas KK (2013), Environmental and socio-economic impacts of salinity intrusion in the coastal area: A case study on Munshigong Union, Shymnagor, Satkhira. Jahangirnagar University Environmental Bulletin 2: 41- 49.
Hossain MS, Khan HR and Akter S (2017), Consequences of Indigenous Organic Amendments and Moisture Conditions on the Growth and Yield of Rice Grown on Saline Soil, International Journal of Science and Engineering Investigations 6: 108-114.

Jackson ML (1973), Soil chemical analysis, Prentice Hall of India Pvt. Ltd., New Delhi, pp 46-183.

Kaniz F and Khan HR (2013), Reclamation of saline soil using gypsum, rice hull, and sawdust in relation to rice production, J. Adv. Sci. Res. 4(3): 1-5.

Khan HR, Bhuiyan MMA and Kabir SM (2016), Effects of selected treatments and techniques for the reclamation and improvement of Cheringa acid sulfate soil under rice production in the coastal plain of Cox's Bazar, $J$. Asiat. Soc. Bangladesh Sci. 42(1): 29-40.

Nelson DW and Sommers LE (1982), Total carbon, organic carbon and organic matter In: Methods of Soil Analysis, Part 2, Ed. Page AL, Agron. Series 9, Am. Soc. Agron. Publ. Madison, WI, USA, pp 539-579.

Olsen SR, Cale CV, Watanabe ES and Dean LA (1954), Estimation of available phosphorus in soils by extraction with sodium bicarbonate, USDA Cric. 939, Washington, USA.

Piper CS (1966), Soil and plant analysis, Hano Publ. Bombay, India.

Polthanee A, Promkhambut A and Kaewrahan S (2011), Growth and Yield of Organic Rice as Affected by Rice Straw and Organic Fertilizer, IJERD 2: 12-18.

Pratt PF (1965), Methods of Soil Analysis, Ed. Black CA, Am. Soc. Agron. Madison, Wisconsin, pp 1022.

Reddy INBL, Kim B, Yoon I, Kim K and Kwon T (2017), Salt Tolerance in Rice: Focus on Mechanisms and Approaches, Rice Science 24(3): 123-144. DOI: org/ 10.1016/j.rsci.2016.09.004

Richards LA(ed) (1954), Diagnosis and improvement of saline and alkali soils In: USDA handbook No. 60, US Govt. Print. Office, Washington, USA, pp 84-156.

Sakai H (1978), Some analytical results of sulfur deficient plants, soil, and water, Workshop on sulfur nutrition in rice, December, BRRI, Publication No. 41: 35-59.

SRDI, Soil Resource Development Institute (2010), Saline Soils of Bangladesh, Ministry of Agriculture, Dhaka, Bangladesh. 